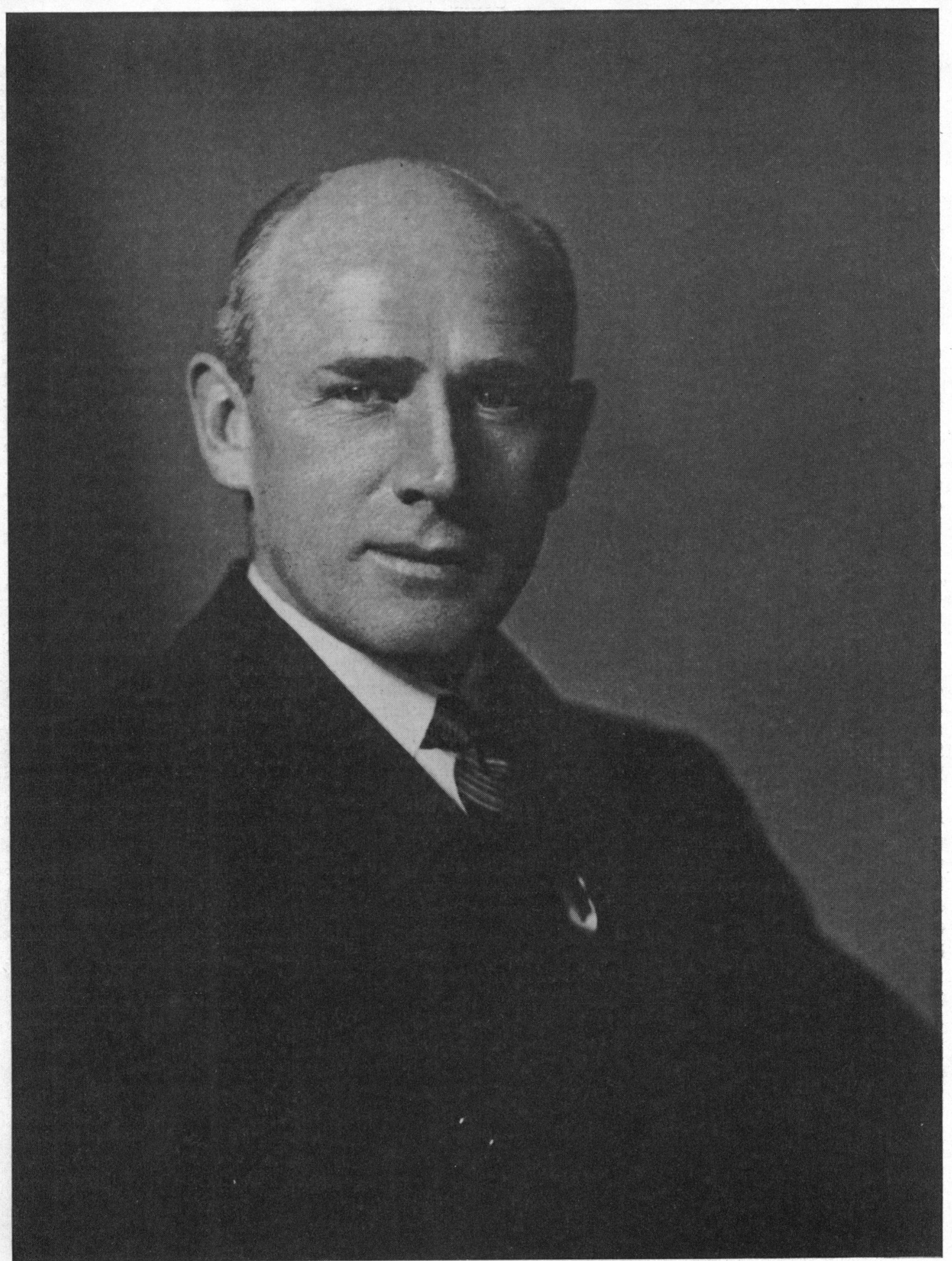




\section{THOMAS FORREST COTTON}

Thomas Forrest Cotton, Consulting Physician to the National Heart Hospital, died in St. Thomas's Hospital on July 25, 1965, aged 80.

Born in the Province of Quebec, Canada, in 1884, and son of Dr. Cedric L. Cotton, he studied medicine at McGill University, graduating in 1909. After resident appointments at the Montreal General Hospital, he visited Europe for postgraduate training in Berlin, Munich, and Paris. In 1913, he came to London to work under Sir Thomas Lewis whom he assisted in an investigation of ventricular hypertrophy, and on his return to Montreal he continued this investigation, the results of which he recorded in Heart (1915-17), 6, 217.

In the early years of the war of 1914, much loss of manpower occurred, owing to rejection of recruits on account of innocent murmurs and to invaliding from France on account of 'Soldiers' Heart'. The advice of the Medical Research Council was sought, and Mackenzie persuaded the War Office to establish a centre at Hampstead for research on heart disorders in soldiers. Mackenzie, Allbutt, and Osler were appointed as consultants, and Lewis, Meakins, and Parkinson were put in charge of separate units, with Cotton, Gunson, and Drury as chief assistants. Parkinson recalls Cotton as the most cheerful and entertaining member of the resident staff and a great favourite of Osler, whose influence was probably responsible for Cotton joining the team. When the hospital moved to Colchester, Cotton went with it as Lewis's chief assistant, and before long others such as Samuel Levine and F. N. Wilson from U.S.A. joined in the work for a time. Amongst the patients at Colchester was Strube, the famous cartoonist, who told me that he was not discharged until he had portrayed every member of the staff; Cotton possessed a complete set of these portraits.

Towards the end of the war, subacute or chronic bacterial endocarditis, then regarded as a rare disease, became prevalent in military and Ministry of Pensions hospitals, and Cotton made an important report to the Medical Research Council based on investigations of this condition at Colchester and later at University College Hospital. At that time clubbing of the fingers was recognized in association with chronic lung disease and congenital heart disease, but its significance as a sign of infection in acquired valve disease was first recognized at Colchester, and Cotton's paper (Heart (1921-22), 9, 347) was an important landmark in the history of this disease.
After the war, Cotton rejoined Lewis at University College Hospital as a part-time worker for the Medical Research Council, co-operating in the investigation of flutter and fibrillation. He set up in private practice as a consultant cardiologist, and his status as Lewis's assistant, together with his free and easy way with patients, ensured rapid success. He gained a reputation for giving a good prognosis in the sense that, however gloomy the situation, he usually succeeded in bringing a more cheerful atmosphere into the sick-room and in giving some encouragement to the patient. In 1924 he was appointed physician to out-patients at the National Heart Hospital, and from that time his interests switched to purely clinical work.

Cotton's special experience of heart disorders in soldiers led to his appointment as consultant cardiologist to the Ministry of Pensions and to Queen Alexandra's Military Hospital, Millbank. The Cardiac Club was initiated by the regional consultants of the Ministry of Pensions, and Cotton was a founder member of the Club, formed in 1922, and later a most regular attender at meetings of the Cardiac Society. He was a keen member of the Osler Club and arranged that the Royal College of Physicians should receive, in due course, a substantial sum of money in return for which the diningroom has been named the Osler Room, Osler's portrait has been hung there, and eventually an annual Osler Oration will be arranged, and a plaque commemorating Thomas Cotton will be placed in the Osler Room.

Joining Lewis in his early days at University College Hospital, Cotton encountered many of the pioneers in cardiology, and his genial personality gained him many friends all over the world, so that he seemed to know everyone. He was a man of the world with wide social contacts; always well informed on current affairs, he invariably had something interesting to say. Not only was he a good raconteur, but also a good listener with a genuine and lively interest in the doings of his fellow men, whether colleagues or patients. His slow, deliberate speech with his slight Canadian accent and what Drury described as his 'couldn't care less' pose, never changed over the years and he retained a certain youthful gaiety of spirit to the end. A lady whom he had treated for many years said to me recently_-'I shall miss his wonderful smile', and what better tribute could a doctor have. When I visited Tom Cotton in hospital shortly before he 
died he was too ill to talk, but nevertheless he smiled at me as serenely as ever and Osler's well-known Address, Aequanimitas, inevitably came to mind in which he said-'no quality takes rank with imperturbability', and Tom was imperturbable to the end.

In 1928, Cotton married Dr. Mary Marshall, then a Clinical Assistant at the National Heart Hospital, who survives him and to whom we extend our sympathy.

D. EVAN BEDFORD

The following are selected as representative of Cotton's more important publications:

1915-17 Observations on hypertrophy. Heart, 6, 217.

1915-17 (With Rapport, D. L. and Lewis, Thomas) After effects of exercise on the pulse rate and systolic blood pressure in cases of 'irritable heart'. Heart, 6, 269.

Observations upon pilocarpine nitrate. ibid., 299.

Observations upon amyl nitrite. ibid., 311.

1918-20 (With Lewis, Thomas)

Observations upon fainting attacks due to inhibitory cardiac impulses. Heart, 7, 23.

1920

Observations on subacute infective endocarditis. Report to the M.R.C. Brit. med.F., 2, 851.

1921 (With Lewis, Thomas)

Observations on flutter and fibrillation. V: certain affects of faradic stimulation of the auricle. Heart. 8, 37.

1921-22 Clubbed fingers as a sign of subacute infective endocarditis. Heart, 9, 347.

1942

1950

Some aspects of carditis. St. Cyres Lecture. Mitral valve disease. Brit. Encycl. Med. Pract. 